\title{
Od „topografii” do Nowej Topografii. Dwie natury ujawnione przez fotografowany krajobraz
}

\section{Wstęp}

Wystawa „New Topographics: Photographs of a Man-Altered Landscape”, otwarta w George Eastman House w Rochester w 1975 roku, prezentowała prace Amerykanów: Roberta Adamsa, Lewisa Baltza, Franka Gohlkego, Johna Deala, Nicolasa Nixona, Johna Schota, Stephena Shore'a, Henry'ego Wessela oraz dwójki Europejczyków: Bernda i Hilli Becherów. Obiektem zainteresowania tych artystów był naznaczony ludzkimi interwencjami krajobraz przedmieść (a w przypadku Becherów - terenów przemysłowych) w Stanach Zjednoczonych i Europie. Nazwa wystawy nawiązywała do „topografii” - popularnego określenia prac takich aktywnych w drugiej połowie XIX wieku twórców, jak Timothy O’Sullivan, William Henry Jackson czy Carleton Watkins. Fotografowali oni krajobraz amerykańskiego Zachodu z nadzieją, że dzięki ich pracom przeciętny Amerykanin wzmocni swój związek z kolonizowaną ziemią i relatywnie młodymi, zachodnimi stanami (Lopes, 2010; Higgbe, 2011). Na zdjęciach jednego z najwybitniejszych przedstawicieli tego nurtu - Timothy'ego O'Sullivana - pojawiają się zarówno krajobrazy pierwotne, „odkrywane” przez kolonizatorów, jak i te już kształtowane przez człowieka. Twórca brał udział w licznych wyprawach organizowanych pod cywilnym lub wojskowym kierownictwem, eksplorujących wciąż mało rozpoznane tereny na zachód od Missisipi. Jego prace nie miały charakteru naukowego, ale ich celem było propagowanie osiągnięć wypraw (Rosenblum, 2005: 143). Fotograf często pokazywał człowieka w konfrontacji z majestatycznymi, pierwotnymi, naturalnymi strukturami. Zwykle umieszczał postacie w perspektywie totalnej, na dole kadru. Zestawiając je z rozległą „dziczą”, uzyskiwał efekt różnicy skali między człowiekiem, jednostką odkrywającą, a otoczeniem naturalnym (w które wpisywał też estetyki cywilizacji Indian) - fascynującym, stanowiącym wyzwanie i dającym obietnicę nowej przestrzeni i zasobów do zagospodarowania. Pokazując ludzkie interwencje, wybierał te o szczególnym cywilizacyjnym znaczeniu - panoramy miast, portów, mosty, 
powstające linie kolejowe. Kształtował w ten sposób mit surowego, lecz zasobnego i rozwijającego się regionu.

Sto lat po inwentaryzacji dokonanej przez „topografów” Nowa Topografia zaprezentowała odmienną wrażliwość wobec Zachodu (Nordström, 2009: 74-75). Ujęty zostaje przez nią przede wszystkim krajobraz przekształcony i sfunkcjonalizowany przez człowieka, w którym samych ludzi zwykle nie widać - za to wyraźnie dostrzec można efekty ich działalności. Tak ukształtowane środowisko pełne jest paradoksów, kontrastów, improwizacji i powtarzalności. Na zarejestrowanych obrazach elementy stworzone przez ludzi i czynniki pozaludzkie przeplatają się w jednym ujęciu. Jednocześnie obrazy ujawniają skalę oddziaływania człowieka i ilość miejsca wykorzystywanego do podtrzymania stworzonego jego rękami systemu.

\section{Nowa wizualna wrażliwość}

Prace wybrane przez Williama Jenkinsa, kuratora wystawy „New Topographics...”, charakteryzowała szczególna, dokumentalna estetyka neutralności. Pozwalała ona odbiorcy skupić się na skali, formach, świetle, fakturach, które cechowały ukształtowane przez człowieka środowisko. Wszelki ruch i postacie zostały zmarginalizowane na rzecz twardej infrastruktury. Wręcz „laboratoryjną” precyzją i oryginalną koncepcją wyróżniali się Becherowie - posługujący się przy wykonywaniu zdjęć konsekwentnie stosowanymi wytycznymi dotyczącymi kadrowania, oświetlenia i jakości zdjęć (Gronert, 2009: 21-24). Mniej restrykcyjni amerykańscy fotografowie także preferowali momenty, gdy uwieczniana przez nich okolica była opustoszała, a jednocześnie dobrze wyeksponowana w dziennym świetle. Wiele ujęć pozwalało widzowi spojrzeć na nią z wysokiej, panoptycznej perspektywy. To, co uderza w owych wypreparowanych z ludzi krajobrazach, to seryjność i powtarzalność: podobne domy przy równo wyznaczonej siatce ulic; obszerne „monokultury" dostosowane do jednej funkcji - mieszkaniowej, handlowej, produkcyjnej. Bez dominant, bez centrum, bez historii.

Krytycy i twórcy analizujący fenomen Nowej Topografii wskazują na kilka źródeł będących inspiracją dla wypracowanej, nowej jakości. Pierwszą z nich są odwołujące się do codzienności i szukające chłodnej, obiektywizującej neutralności prace Walkera Evansa, dokumentalisty współpracującego z rządowymi agencjami i prasą (m.in. „Fortune” i „Time”), którego najwybitniejsze prace pochodzą z czasów Wielkiego Kryzysu lat trzydziestych XX wieku. Początkowo Evans chciał zostać pisarzem. Fascynowała go twórczość Jamesa Joyce’a i Ezry Pounda. W latach dwudziestych XX wieku wyjechał do Paryża, gdzie studiował na Sorbonie i zainteresował się 
francuskim surrealizmem. Po powrocie do kraju w swojej twórczości zwrócił szczególną uwagę na pełną kontrastów i krzykliwych reklam przestrzeń wielkich amerykańskich miast. Jednak ogromny wpływ na Nową Topografię miały jego prace z okresu Wielkiego Kryzysu. Pokazanie rzeczywistości bez oskarżycielskiego tonu, bez szukania ekstremum i idealizacji - to założenie Evansa fascynowało nowych dokumentalistów amerykańskiego Zachodu. Jon Szarkowiski - kurator i redaktor katalogów o twórczości Evansa - piał, że jego prace wykonane są w „dokumentalnym stylu”, podkreślając, że celowo nie określa ich jako „fotografii dokumentalnej”, która według niego jest bardzo mylącym i mętnym terminem (Salvesen, 2009: 16).

Szczególną wrażliwość na architekturę, która inspirowała Nowa Topografię, odnajdziemy w twórczości Dana Grahama. Homes for America z 1968 roku to praca w formie artykułu w magazynie, zawierająca fotografie i tekst. Graham skrupulatnie rejestrował niewielkie różnice w stylu i kolorze budowanych masowo przez deweloperów domów i analizował estetykę tej architektury - łączącą pragmatyczny minimalizm z formami nawiązującymi do tradycyjnego budownictwa. Pierwotnie praca miała zostać opublikowana w poczytnym czasopiśmie, takim jak „Esquire”, jednak ostatecznie jej mocno okrojona wersja trafita do specjalistycznego „Arts Magazine”.

Kolejnym twórcą wnikliwie obserwującym banalną rzeczywistość Ameryki lat sześćdziesiątych XX wieku był Ed Ruscha. Jego cykle fotografii Twentysix Gasoline Stations (1963) czy Every Building on the Sunset Street (1966) stanowity refleksję nad zmieniającym się, a jednocześnie powtarzalnym krajobrazem ukształtowanym przez człowieka, widzianym z perspektywy kierowcy samochodu. Twentysix Gasoline Stations prezentowała dokumentalne zdjęcia wybranych stacji benzynowych przy drodze numer 66, prowadzącej z Oklahoma City do Los Angeles. Twórca wydawał swoje fotografie $w$ formie niskonakładowych wydawnictw, które nie sugerowały przedsięwzięcia artystycznego.

Dla twórców Nowej Topografii Rusha był kontrowersyjną i znaczącą postacią. Baltz i Shore nie kryli podziwu dla jego prac. Nixon twierdzit, że idea prac Ruschy jest dobra, ale był krytyczny wobec ich wykonania. Dla Adamsa, którego intencją było „odkrycie nieironicznego współczesnego świata”, Rusha jawił się jako zbyt ironiczny (Salvesen, 2009: 26-27). Oglądając prace Ruschy i Grahama, widzimy przede wszystkim zagospodarowane przez człowieka środowisko w jego masowym, przeciętnym wydaniu. W pracach Nowej Topografii możemy dostrzec coś jeszcze - delikatną i zaskakująco odległą granicę między przestrzenią człowieka (coraz słabiej widoczną) a strefą niepodlegającą jego interwencji; nieaktualność rozgraniczenia tego, co ludzkie i naturalne, tak wyraziście pokazanego na fotografiach z XIX wieku. 


\section{Obca codzienność Zachodu}

Krajobrazy wypełnione przez seryjną architekturę oraz infrastrukturę samochodową i energetyczną ujawniają niejednoznaczne oblicze wygodnego i nowoczesnego środowiska życia mieszkańców amerykańskiego Zachodu. Rozległe monokultury wtopione w energetyczną i drogową infrastrukturę tworzą ,pustynie wykonane ręką człowieka" (Ratcliff, 1976: 86). Choć mamy do czynienia z nowoczesnymi obiektami stworzonymi dla ludzi, wcale nie odnosimy wrażenia, że człowiek jest w nich najważniejszy. W opustoszałych przedmieściach z prac Nowej Topografii zwracają uwagę proporcje domów do otaczającej je infrastruktury transportowej i energetycznej. Wtopione w nią sześciany wydają się przytłoczone rozbudowaną siecią podporządkowaną celom gospodarczym. Nowa Topografia w ten sposób pokazuje środowisko ukształtowane przez człowieka, które jest wynikiem nie tylko jego bezpośredniej interakcji z otoczeniem, ale też wielu decyzji i procesów o ponadlokalnym znaczeniu, których skala nie miała w przeszłości precedensu. „Nie zamieszkujemy już domów, lecz ukrywamy się w ich ruinach, przez które przedziera się komunikacyjna zamieć" - zauważył w krótkim, syntetycznym tekście Architektura przyszłości Villém Flusser (2016: 185). Filozof nakreśla koniec ostoi stałości i skrytości, jaką był dom. Materialne i niematerialne kable wdarły się do niego, kwestionując jego rolę miejsca ochrony i wytchnienia przed „siłami wyższymi”. Dom stał się przede wszystkim punktem w gęstej sieci społecznej, wprzęgniętym w wymianę informacji i procesy produkcyjne. Flusser postuluje myślenie o domu już nie jako o miejscu geograficznym, lecz topologicznym. Mieszkańcy nowych domów mają być zajęci budowaniem rozległych sieci komunikacji i interakcji. Wszystko, co służy jej podtrzymywaniu, wydaje się na fotografiach Nowej Topografii trwałe i rozległe, same domy zaś improwizowane, niedrogie lub przystosowane do przemieszczania się. Zachód, którego bezprecedensowa kolonizacja i zmagania o własne miejsce wydają się epoką zamkniętą, po stu latach nie „osiadł”, wprawiony w ruch przez nową technologię i ekonomię. Flusser w architekturze przyszłości widzi „nietechniczne (egzystencjalne) niebezpieczeństwo. Ludzie, którzy zamieszkują tego typu domy, nie będą mieli się gdzie skryć (żadnego dachu, żadnej ściany), nie będą mieli nic, czego mogliby się przytrzymać" - ostrzega (Flusser, 2016: 186).

Nowa Topografia, eliminując ruch człowieka i maszyn, a pokazując wyabstrahowane środowisko stałych obiektów, budzi w odbiorcy dysonans poznawczy. Fenomen ten ilustruje wypowiedź Colina Westerbecka, który tak opisuje prace Roberta Adamsa: „W fotografiach Adamsa trafiamy na architekturę jak na element natury pozostawiony wieki temu przez jakieś prabestie" (Tagg, 2010: 445). 
Wrażenie opuszczenia łatwo uzasadnić - fotograficy celowo wybierali momenty i miejsca, w których ludzie pozostawali niewidoczni. Intrygujące pozostaje pytanie, dlaczego amerykańskie przedmieścia skojarzyły się krytykowi z czymś odległym, obcym i - dlatego właśnie - naturalnym.

\section{Obrazy jako reprezentacja pojęcia natury}

Pojęcia natury i przyrody zanurzone są w codziennym doświadczeniu jednostek żyjących w konkretnym miejscu i czasie oraz konkurują ze sobą - twierdzą Phill Macnaghten i John Urry (2005). Ograniczając się do kręgu kultury północnoatlantyckiej, ci dwaj socjologowie zaproponowali wyodrębnienie najbardziej wyrazistych i wpływowych koncepcji na przestrzeni epok. Na postrzeganie natury i przyrody w XIX wieku ogromny wpływ wywart romantyzm. Amerykańskie topografie reprezentują kierunek myślenia o krajobrazie naturalnym jako czynniku określającym tożsamości mieszkańców danego państwa i regionu (Macnaghten, Urry, 2005: 163). To w XIX wieku zaczęto najbogatsze przyrodniczo, a jednocześnie najbardziej spektakularne krajobrazy chronić przed ludzką interwencją (pierwszy obszar ścisłej ochrony, przekształcony potem w park narodowy, powstał w 1864 roku w USA). Docenienie wartości pierwotnego krajobrazu paradoksalnie sprawiło, że „obszary naturalne" stawały się czymś bardzo odmiennym, odrębnym, autonomicznym od tego ukształtowanego przez cywilizację. Wytworzyło to silne poczucie odseparowania natury i kultury. Potwierdza to wypowiedź Westerbecka o obcość jako czymś równoznacznym z naturą (Tagg, 2010: 445). W pracach „topografów” widać fascynację tym, co spektakularne, unikatowe i trudno dostępne: naturą nietkniętą przez człowieka oraz pionierskimi, ludzkimi osiągnięciami w przekształcaniu środowiska (rozwijające się miasta, trasy kolejowe itp.). Pozbawiona wzniosłości przeciętność i banalność, miejsca styku natury i kultury nie były istotnym przedmiotem ich zainteresowania.

Nowa Topografia jest więc nie tylko zwrotem estetycznym czy wyrazem ówczesnej wrażliwości, ale i komunikatem subwersywnym wobec pojęcia natury, wywodzącego się ze świadomości dziewiętnastowiecznej. Wymowny staje się w tym kontekście tytuł wystawy. Słowo „nowy” (new) wyrażało ambicje stworzenia czegoś oryginalnego, a nie tylko współczesnego (contemporary). Zawarte w tytule słowa „zmodyfikowany przez człowieka krajobraz” (man-altered landscape) - a nie na przykład „zmodyfikowana przez człowieka przestrzeń” - sprawiły, że wielu krytyków zastanawiało się, czy wystawa nie jest zakwestionowaniem samego gatunku (Salvesen, 2009: 41). Gdy Adams, Baltz i Shore fotografowali amery- 
kańskie przedmieścia, upowszechniała się już inna koncepcja natury: rozumianej jako środowisko złożone i funkcjonujące dzięki skomplikowanym zależnościom między elementami. Lata siedemdziesiąte XX wieku - epoka zimnowojennej doktryny $M A D^{1}$ oraz sugestywnych obrazów delikatnej planety wykonanych przez astronautów misji Apollo - zaowocowały „fundamentalną zmianą w myśleniu o obopólnych relacjach człowieka wobec otoczenia i jednocześnie głównym filarem pojęciowo-teoretycznym najnowszej humanistyki" (Jelewska, 2014: 241). Wówczas zaczęto doceniać i opracowywać nowe holistyczne ujęcia natury i poszukiwać odpowiednich do ich opisu pojęć. Jedną z koncepcji, która zyskała popularność, była biosfera, rozumiana w ujęciu geochemika Władimira Wiernadskiego jako energetyczno-mineralny system, formujący Ziemię w ciągu całego biogeologicznego czasu (Jelewska, 2014: 158). Na początku lat siedemdziesiątych XX wieku dwaj biolodzy, Humberto Maturana i Francisco Varela, opisali istoty żywe, rozwijając teorię systemów autopojetycznych Niklasa Luhmanna. W centrum tej koncepcji pojawiły się rozpatrywane niehierarchicznie, różnorodne, złożone, samokonstytuujące się, samoodnoszące się oraz samoorganizujące się systemy. Znacznie dalej wykraczała kontrowersyjna metafora biologa Jamesa Lovelocka, który zaproponował spojrzenie na całą Ziemię jako na jeden żywy, samoregulujący się organizm. Wpływ nowego myślenia widać w amerykańskiej kontrkulturze i sztuce. Neoawangarda lat siedemdziesiątych XX wieku - będącą „środowiskiem” Nowej Topografii - z zainteresowaniem eksplorowała nowe koncepcje natury. Twórcy reprezentujący nurty, takie jak land art, environment, happening czy performance art, opuszczali galerie, by swoją aktywność koncentrować na poszukiwaniu sztuki jako sposobu budowy relacji ze środowiskiem.

Koncepcje upowszechniające się w latach siedemdziesiątych XX wieku „konkurowały” i wciąż „konkurują” z osadzonym silnie w powszechnej świadomości podziałem na to, co społeczne (sztuczne, stworzone przez człowieka) i naturalne (wrodzone, pierwotne). Do powszechnej świadomości idee postrzegania natury jako całości życia na Ziemi docierały ze względu na kryzysy ekologiczne i globalne wyzwania w zakresie ochrony środowiska. Jednym z najważniejszych był moment, gdy państwa i instytucje na całym świecie musiały zmierzyć się z niepokojącymi badaniami świadczącymi o spadającym stężeniu ozonu w stratosferze atmosfery ziemskiej - na co reakcją było porozumienie podpisane w Montrealu 16 września 1987 roku.

1 Mutual Assured Destruction (zagwarantowane wzajemne zniszczenie) - doktryna wojskowa, polegająca na utrzymywaniu środków, które potencjalnie mogą wywołać tak dotkliwe straty u przeciwnika, że wywołanie konfliktu na pełną skalę staje się nieracjonalne. 


\section{Podsumowanie}

Pojęcie natury odseparowanej od kultury zaczęto rozpatrywać w kontekście problemów relacji człowieka z tym, co pozaludzkie - uwzględniając wzajemne oddziatywanie, ukrytą sprawczość, widoczność i niewidoczność zachodzących procesów. Przykładem przełamania bezpiecznej dychotomii natury i kultury jest propozycja wyodrębnienia antropocenu - nowej epoki geologicznej, w której za sprawą postępu technologicznego i masowej industrializacji człowiek stał się głównym czynnikiem zmieniającym przyrodnicze procesy oraz środowisko. Koncepcja antropocenu zakłada, że zmiany dokonywane przez człowieka są już prowadzone na tak dużą skalę, że epoka holocenu powinna zostać uznana za historyczną.

W związku z historyczną perspektywą i ze świadomością złożoności procesów mających miejsce w środowisku zachodzące w nim zmiany coraz trudniej jest określać jako „naturalne”, „zgodne z naturą” lub będące „powrotem do natury”. Jednym z najbardziej radykalnych myślicieli analizujących ten problem jest Timothy Morton. Uważa on pojęcie natury za współcześnie zbyt zideologizowane i niejasne, za bardziej produktywny i adekwatny do współczesnej sytuacji antropocenu termin uznając ekologię (Morton, 2007). Morton zaproponowat wspólną płaszczyznę dla różnych pojęć natury. Twierdzi, że ludzkość łączyła to pojęcie przez tysiąclecia z harmonijnym cyklem zmian, uosabianym przez pory roku. To wyobrażenie było możliwe dzięki zaistnieniu agrokultury we względnie stabilnej epoce geologicznej, jaką był holocen (Morton, 2016: 58). Cykliczna natura - zmienna, ale powracająca do stanu równowagi - wywołuje graniczącą z pewnością nadzieję, że nawet po klęskach i budzących zwątpienie chwilach samoistnie dokona regeneracji. Spojrzenie na naturę jako cykl objawiało się wyraźnie w kulturze - szczególnie w rytuałach i obrzędowości. W tym ujęciu natura rządzi się swoimi prawami - niezależnymi od człowieka, który nie może się mierzyć z jej siłą. Taka odrębna natura - wymagająca raz ochrony, a innym razem okiełznania - wyłania się z prac „topografów”. Nowa Topografia uchwyciła krajobrazy, które stapiają ludzkie interwencje z innymi pozaludzkimi elementami, pokazując konkretne, osadzone w czasie, przestrzeni i historii środowisko. Jej rytmem nie są cykliczne zmiany, ale informacyjny i produkcyjny performans odbywający się codziennie, dwadzieścia cztery godziny na dobę, w który wprzęgniętych jest wiele czynników - widocznych i niewidocznych, ale na pewno nieodseparowanych i osobnych. 


\section{Bibliografia}

Flusser V. (2016), Architektura przyszłości, „Kultura Współczesna”, nr 4(92), s. 183-186.

Gronert S. (2009), The Dusseldorf school of photography, New York: Aperture.

Higgbe L. (2011), Reinventing the Genre: New Topographics and the Landscape, https://www.academia.edu/1947419/Reinventing_the_ Genre_New_Topographics_and_the_Landscape (dostęp: 23.06.2020).

Jelewska A. (2014), Ekotopie. Ekspansja technokultury, Poznań: Wydawnictwo Uniwersytetu im. Adama Mickiewicza w Poznaniu.

Lopes S. (2010), New (and Old) Topographics, „Places Journal”, March, https://doi.org/10.22269/100303

Macnaghten P., Urry J. (2005), Alternatywne przyrody. Nowe myślenie o przyrodzie i społeczeństwie, przeł. B. Baran, Warszawa: Wydawnictwo Naukowe Scholar.

Morton T. (2007), Ecology without Nature. Rethinking Environmental Aesthetics, Cambridge-London: Harvard University Press.

Morton T. (2016), Dark Ecology. For a Logic of Future Coexistence, New York: Columbia University Press.

Nordström A. (2009), After New: thinking about New Topographics from 1975 to Present, [w:] B. Salvesen (red.), New topographics, New York: Center for Creative Photography, University Arizona, Georg Eastman House International Museum of Photography and Film, Steidl, s. 69-79.

Ratcliff C. (1976), Route 66 Revisited: The New Landscape Photography, „Art in America”, January/February, s. 86-91.

Rosenblum N. (2005), Historia fotografii światowej, przeł. I. Baturo, Bielsko-Biała: Wydawnictwo Baturo.

Salvesen B. (2009), New topographics, [w:] B. Salvesen (red.), New topographics, New York: Center for Creative Photography, University Arizona, Georg Eastman House International Museum of Photography and Film, Steidl, s. 11-67.

Tagg J. (2010), Nieciagłe miasto: fotografia i pole dyskursu, [w:] E. Rewers (red.), Miasto w sztuce - sztuka miasta, Kraków: Wydawnictwo Universitas, s. 440-447. 